\title{
IDENTIFICATION OF PRECAST PARAPET WORK ACTIVITIES IN ELEVATED RAILWAY CONSTRUCTION
}

\author{
Pungky Dharma Saputra ${ }^{1}$ \\ ${ }^{1}$ Military Building Construction Engineering Study Program, Faculty of Military Engineering, Indonesia \\ Defense University, Bogor, 16810, Indonesia \\ e-mail:ir.pungky@gmail.com ${ }^{1}$
}

\begin{abstract}
Railway infrastructure development is very massive in Indonesia. Many projects have been constructing since 2013, such as the Mass Rapid Transit (MRT), Light Rail Transit (LRT), Double-Double Track (DDT), and High-Speed Rail (HSR). And all of these projects were design with elevated structures. When applying precast parapet panel technology in the MRT project elevated section, the contractor didn't have a reference for precast parapet work activities. Hence, it required new planning for its construction and took time. The project sample of this research was MRT Jakarta CP 103 Project. There were three stages in this research starting from documentation analysis, expert judgment, and respondent survey. There were 5 bridge construction experts and 30 respondents which were professional engineers asked for their recommendations and opinions. Descriptive analysis was applied to know the percentage of opinions. This research focuses on identifying precast parapet activities in elevated railway construction project. There are 14 activities that had been identified in this research, namely preparation, position survey, adjustment material installation, precast parapet panel shifting from trailer to the top of deck slab, precast parapet panel distribution, precast parapet panel installation, rebar parapet installation for concrete stitch, sealing work, concrete casting, formwork dismantling, and finishing. These activities will be very useful for similar precast parapet works in a future project.
\end{abstract}

Keywords: Work Activities; Precast Parapet Panel; Elevated Railway Project

\section{INTRODUCTION}

Railway infrastructure development is very massive in Indonesia. Many projects have been constructing since 2013, such as Mass Rapid Transit (MRT) Jakarta, Light Rail Transit (LRT) Jabodebek \& Palembang, DoubleDouble Track (DDT), and High-Speed Rail (HSR) Jakarta - Bandung. MRT Jakarta project was the milestone in railway infrastructure development in Indonesia, starting in 2013 and finish 2019 (PT MRT Jakarta, 2020). In 2017, The Indonesian government had released the accelerated infrastructure development rules which include the development of railway infrastructure throughout Indonesia (Setkab RI, 2017).
Currently, the railway infrastructures are built with the latest technology of elevated construction. The use of precast parapet in elevated constructions is still relatively new in Indonesia. Precast parapet panel technology was used for the first time in the MRT Jakarta CP 101, 102, and 103 Projects with elevated constructions. There was no reference to use this new technology hence it requires new construction planning and took time. Though, every project requires detailed activities that can guide the construction execution and can run effectively (Latief et al., 2019). It means that the detailing of work activities is very important for construction execution (Latief et al., 2019).

In construction, every activity will be executed by the project team to achieve 
project goals (Rad, 1999), namely cost, quality, time, and safety. Hence, activities or series of tasks are very attached to a construction project and can not be separated from each other (Elsye, et al., 2018). Activities are defined by work breakdown structure or in other words, activities are generated by work breakdown structure (Elsye et al., 2018).

Base on the method statement of work that had been developed, the workflow of precast parapet panel construction work starting from a survey, material adjusting installation, precast parapet panel unloading, precast panel distribution, precast panel installation, and, stitch concreting (OSJ-JV, 2017). This workflow has to be broken down again because there are insert activities that were not shown. Therefore, it is necessary to identify detailed activities to be clear. Precast parapet panel installation is shown in Figure 1.

Activities in elevated constructions had been studied in some previous research. However, those only explained the work breakdown structure of precast girder erection in elevated road generally (Kurnia, et al., 2018). Furthermore, there were researches only explained PCI girder erection with the crane and launching gantry method (Saputra \& Latief, 2020a; Saputra \& Latief, 2020b). Those researches did not explain precast parapet work. Whereas, precast parapet panel will continue to be used in future elevated projects which will be constructed. This makes research on precast parapet work activities is very important and must be conducted immediately considering the benefits in the future. In the end, it is a novelty in the elevated construction project, especially in Indonesia.

To develop and complement previous research on elevated construction work activities, the main focus of this research is precast parapet work activities identification in railway elevated construction. To be more focused, this research is limited only to the activities of precast parapet panel work on elevated construction, especially the railway project. This research is expected able to develop a previous standardized work breakdown structure and can be a reference for future similar precast parapet panel work package in railway elevated construction.

\section{METHODS}

\section{Research Design}

This research was designed as exploratory research that measures the opinions of experts and experienced respondents about the precast parapet panel work activities hence the results can be described as the basis for the implementation of construction in the site and further research. The approach applied was a quantitative approach with a survey.

\section{Variables}

The variables which will be studied in this research are work activities in precast parapet panel work for elevated railway construction project.

\section{Stages of The Research Method}

This research was designed in 3 stages to achieve the research objective (See Figure 2.). The first stage is to conduct documentation analysis to identify precast parapet panel construction sequences and activity. Furthermore, the experts were asked to validate the precast parapet panel activities that had been identified. This stage was called expert judgment (PMI, 2017). In the last stage, a survey was conducted of 30 experienced bridge engineers to collect their opinion about the detailed activities of precast parapet panel works that had 
been identified. The detailed stages of research are shown in Table 1.

\section{Questionnaire}

The questionnaire was designed using the Guttman scale. It was used to know expert's and respondent's opinions by choosing "yes" or "no" options (Sugiyono, 2018). The questionnaire was distributed in two stages. In the first stage, the questionnaire was distributed to the experts. And the last stage, the questionnaire will be redeveloped and modified according to the expert recommendation and distributed to the respondents.

\section{Project Sample}

The project sample was used in this research was MRT Jakarta CP 103 Project Elevated Section. This project was chosen because precast parapet panel work in bridge structure was applied for the first time in Indonesia.

\section{Experts and Respondents}

The expert's requirements should have more than 10 years of working experience in bridge constructions, a bachelor's degree in education background, and should be professional engineers or academicians with minimum qualification as a project manager, site operational manager, and site engineering manager. The expert's profile is shown in Table 2. The respondent requirements should have more than 5 years working experience in bridge constructions, a bachelor's degree in educational background, and should be a minimum junior professional engineer.

\section{Analysis Technique}

Because this research is exploratory research, the data analysis technique used is descriptive statistical analysis. This analysis is used to determine the percentage opinion of the experts and respondents regarding the precast parapet panel work activities.

After all, data is collected from experts and respondents then they are grouped, compiled and analyzed, and presented in tables.

\section{RESULTS AND DISCUSSION}

\section{Expert Judgment Result}

The analysis results show that there were 12 activities of precast parapet panel works that were validated by the experts. They were position survey, adjustment material installation, precast parapet panel shifting from trailer to the top of deck slab, precast parapet panel distribution, precast parapet panel installing, precast parapet panel fixing, rebar installation for concrete stitch, formwork installation for concrete stitch, sealing work, concrete casting, and formwork dismantling. The results of expert judgment are shown in Table 3.

The activities which were identified are validated by the construction expert in bridge engineering. The experts agree that the activities are valid with a total percentage are greater than $80 \%$ in each activity. Then the experts recommend adding "preparation" activity as the first sequence of work and "finishing" activities as the final sequence. This recommendation will be added to the next survey stage and data analysis.

\section{Respondent Survey Result}

Base on the analysis results, all of the respondents have 10 years of working experience. Most of them are engineers responsible for bridge superstructure work. Respondents with a master degree were 5 peoples, a bachelor degree was 22 peoples and a diploma degree were 3 peoples. The respondents were not only from Indonesia but also from Japan and 
the Philippines. The respondent profiles are shown in Table 4.

The respondents agree that the activities in the precast parapet panel work with a total percentage are greater than $80 \%$. It means that the activities which had been asked in the questionnaire were agreed upon by almost all respondents. There were 3 activities that had a percentage lower than $100 \%$. They were precast parapet panel shifting from trailer to the top of deck slab (86.67\%), precast parapet panel distribution (93.33\%), and sealing work $(83.33 \%)$. The detailed results are shown in Table 5.

\section{Discussion}

In project management, project activities are important to be identified. This can make a good project management implementation (Tozahro \& Nursin, 2020). Because that has a function to achieve project goals (Rad, 1999) and minimize the constraints (Tozahro \& Nursin, 2020). The project can be managed easily because of the activities identified at the beginning of the project (Yilmaz \& Kanit, 2018). The activities are at level 5 of a work breakdown structure after the project name (level 1), work section (level 2), sub work section (level 3), and work package (level 4) (Kurnia et al., 2018; Pratita \& Latief, 2018; Satrio \& Latief, 2018; Al Farizi \& Latief, 2018; Amini \& Latief, 2018; Aryanto, et al.). Precast parapet panel works in this research case is at work package level or level 4. The precast parapet panel work package is structured and developed based on the activities identified at level 5. Identification of activities is also based on the selection of design and construction methods used because different designs and construction methods will generate different activities (Latief et al., 2018). In this study, the design used is the precast parapet panel and the method used is the lifting crane method.

The analysis shows that there were 14 activities in precast parapet panel works. These activities are detailed and sequential activities based on the planned construction method, namely the lifting crane method. The activities start from preparation, position survey, adjustment material installation, precast parapet panel shifting from trailer to the top of deck slab, precast parapet panel distribution, precast parapet panel installing, precast parapet panel fixing, rebar installation for concrete stitch, formwork installation for concrete stitch, sealing work, concrete casting, and formwork dismantling, and the last sequence is finishing work.

The work breakdown structure is the basis of project management which is part of the scope management that will determine the successful project performance. It generates a detailed and complex level of work (Hidayah et al., 2018). Therefore, these identified activities are part of the development of the work breakdown structure and they are depicted at the lowest task level of the work breakdown structure tree diagram in Figure 3. The development of the work breakdown structure is started from level 4 (work package) and level 5 (work activity). According to the definition, work breakdown structure describes the task levels ranging from general works to specific works (PMI, 2017). This work breakdown structure has important functions as the basis for project scope management ( $\mathrm{Su}, 2012)$, time and schedule management, human resources management, cost management, risk management, supervising, monitoring, and control (PMI, 2017). Thus, it is very useful for similar precast parapet works in a future project. 


\section{CONCLUSION}

There are 14 activities that had been identified in this research, namely preparation, position survey, adjustment material installation, precast parapet panel shifting from trailer to the top of deck slab, precast parapet panel distribution, precast parapet panel installation, rebar parapet installation for concrete stitch, sealing work, concrete casting, formwork dismantling, and finishing. The activity identification results can be integrated into the work breakdown structure that had been developed and can be used as a reference for similar work in the future. The research result can be developed in future research in measuring cycle time, developing a safety plan, quality plan, standard operating procedure of precast parapet panel, and integrating with building information management (BIM).

\section{ACKNOWLEDGEMENT}

The author would like to thank the experts, respondents for giving the opinion on this research and also to the construction company which had permitted to access the project.

\section{REFERENCE}

Al Farizi, S., \& Latief, Y. (2018). Development of standardized WBS (Work Breakdown Structure) for planning the schedule based on risk in Steel Bridge construction projects. Proceedings of the International Conference on Industrial Engineering and Operations Management, 757-762, IEOM Society.

Amini, R. A., \& Latief, Y. (2018). Development of Risk-Based Standardized WBS (Work
Breakdown Structure) for Quality Planning of Road Construction Project. Proceedings of the International Conference on Industrial Engineering and Operations Management, Bandung, Indonesia.

Aryanto, D. V., Supriadi, L. S. R., \& Latief, Y. (2020). Development of WBS Dictionary and Checklist Based on WBS of Railway Construction for Safety Planning. IOP Conference Series: Materials Science and Engineering, 1007(1), $012007 . \quad$ doi:10.1088/1757899X/1007/1/012007

Elsye, V., Latief, Y., \& Sagita, L. (2018). Development of work breakdown structure (WBS) standard for producing the risk based structural work safety plan of building. MATEC Web of Conferences, 147, 06003, EDP Sciences. doi: 10.1051/matecconf/20181470600 3

Hidayah, D. N., Latief, Y., \& Riantini, L. S. (2018). Development of work breakdown structure standard based on risk for safety planning on dam construction work. IOP Conference Series: Materials Science and Engineering, 420(1), 012003, doi:10.1088/1757899X/420/1/012003

Kurnia, R. F., Latief, Y., \& Riantini, L. S. (2018). The Development of Risk Based Standardized WBS (Work Breakdown Structure) for Cost Estimation of Concrete Precast Bridge Construction. Proceedings of The International Conference on Industrial Engineering and Operations Management. Bandung, Indonesia.

Latief, Y., Kusumaningtyas, G. R. \& Supriadi, L. S. R. (2018). Work Breakdown Structure (WBS) 
Dictionary Development for The Construction Works of Fly Over Projects. IOP Conf. Series: Earth and Environmental Science, 195, 012003. doi:10.1088/17551315/195/1/012003

Latief, Y., Nurdiani, D., \& Supriadi, L. S. R. (2019) Development of Work Breakdown Structure (WBS) Dictionary for The Construction Works of Lower Structure Steel Bridge. MATEC Web of Conference, 258, 02003. doi: $10.1051 /$ matecconf/20192580200 3

OSJ-JV. (2017). Method Statement for Precast Parapet Construction. OSJ-103-CMN-MST-STR-0079 Rev D.

PMI. (2017). Project Management Body of Knowledge. Pennsylvania: Project Management Institut, Inc.

Pratita, M. W. A. S., \& Latif, Y. (2018). Development of risk-based standardized WBS (Work Breakdown Structure) for quality planning of flyover works. Proceedings of the International Conference on Industrial Engineering and Operations Management, IEOM, 2694-2710.

PT MRT Jakarta. (2020). Sejarah PT Mass Rapid Transit (MRT) Jakarta. October $2^{\text {nd }}, 2020$ at 09.00 am.

https://jakartamrt.co.id/id/sejarah .

Rad, P. F. (1999). Advocating a deliverable-oriented work breakdown structure. Cost Engineering, 41(12), 35-39.

Saputra, P. D. \& Latief, Y. (2020a). Development of Safety Plan Based on Work Breakdown Structure to Determine Safety Cost for Precast Concrete Bridge Construction Projects. Case Study: Girder
Erection with Launching Gantry Method. Civil Engineering and Architecture, 8(3), 297-304.

Saputra, P. D. and Latief, Y. (2020b). Analysis of Safety Cost Structure in Infrastructure Project of Precast of Precast Concrete Bridge base on Work Breakdown Structure (WBS). IOP Conference Series: Materials Science and Engineering, 830(2), 022074, doi:10.1088/1757-899X/830/2/ 022074

Satrio, G. \& Latief, Y. (2018). Development of Risk-Based Standardized WBS (Work Breakdown Structure) for Safety Planning of Cable-Stayed Bridge Project. Proceedings of the International Conference on Industrial Engineering and Operations Management, 12(2), 110-117.

Sugiyono. (2018). Metode Penelitian Kuantitatif. Bandung: Alfabeta.

Tozahro, N. \& Nursin, A. (2020). Last Planner System (LPS) Implementation on JakartaCikampek II Elevated Toll Road Project. Applied Research on Civil Engineering and Environment (ARCEE), 02(01), 17-22.

Yilmaz, M., \& Kanit, R. (2018). A practical tool for estimating compulsory OHS costs of residential building construction projects in Turkey. Safety science, 101, 326-331. 


\section{Appendix}

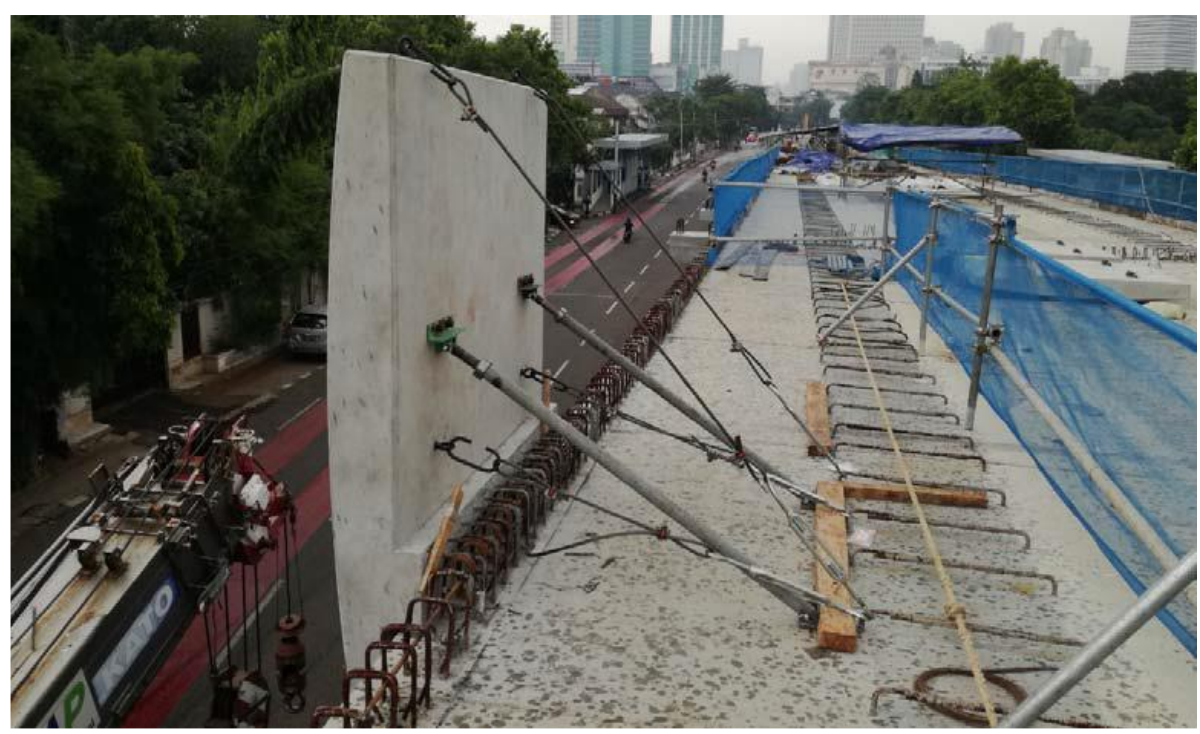

Figure 1. Precast Parapet Panel Installation (OSJ-JV, 2017)

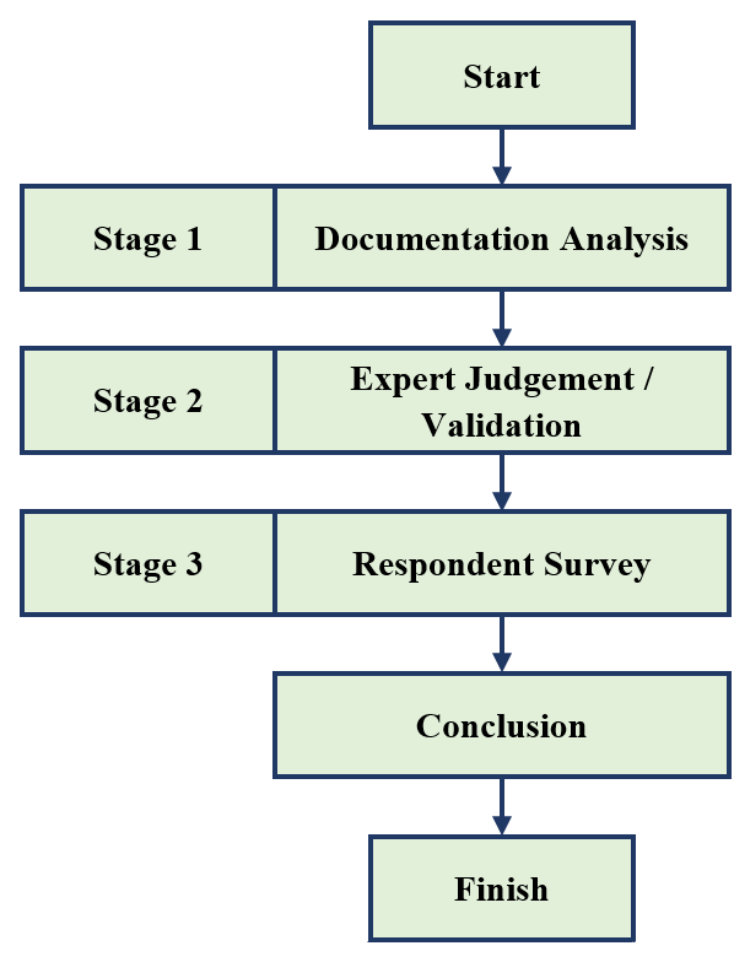

Figure 2. Research Flow 


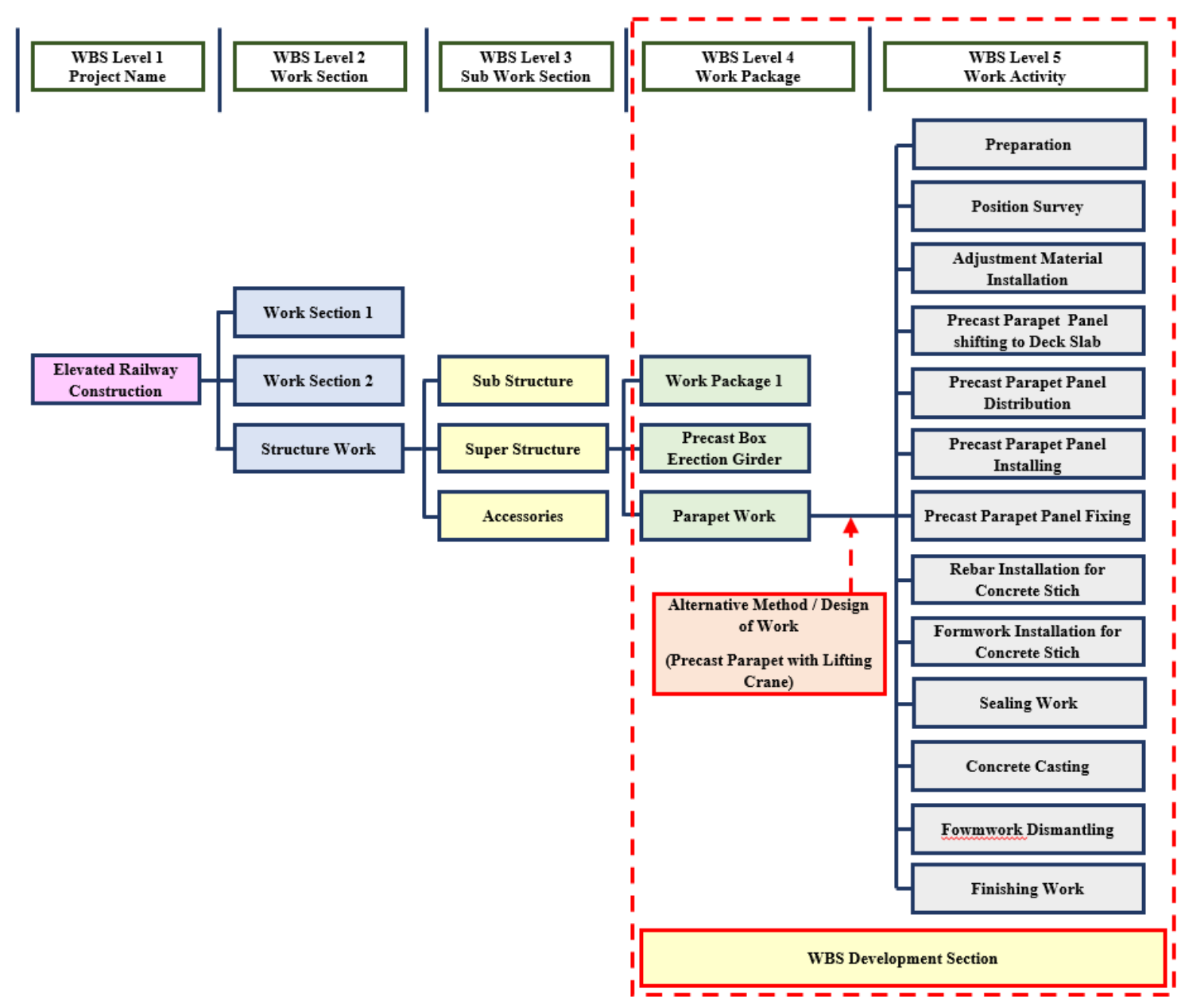

Figure 3. WBS Tree Diagram with Detail Activities of Precast Parapet Work 
Table 1. Stages of The Research

\begin{tabular}{lccc}
\hline Stage & Stage 1 & Stage 2 & Stage 3 \\
Method & $\begin{array}{c}\text { Documentation } \\
\text { Analysis }\end{array}$ & Expert Judgement & Respondent Survey \\
Variables & \multicolumn{2}{c}{ Activities of Precast Parapet Work Installation } \\
Samples & MRT CP 103 Project & Construction Expert & Respondent \\
Questionnaire & No & Guttman Scale \\
Analysis & No & Descriptive Analysis \\
\hline
\end{tabular}

Table 2. Expert Profile

\begin{tabular}{cccccc}
\hline No & Expert & $\begin{array}{c}\text { Working } \\
\text { Experience }\end{array}$ & Position & Education & $\begin{array}{c}\text { Country of } \\
\text { Origin }\end{array}$ \\
\hline 1 & Expert 1 & 30 Years & General Manager & Master Degree & Japan \\
2 & Expert 2 & 30 Years & Project Manager & Master Degree & Japan \\
3 & Expert 3 & 25 Years & Site Manager & Master Degree & Japan \\
4 & Expert 4 & 17 Years & Chief of Engineer & Master Degree & Philippines \\
5 & Expert 5 & 15 Years & Engineering Manager & Bachelor Degree & Indonesia \\
\hline
\end{tabular}

Table 3. Expert Judgement Results

\begin{tabular}{|c|c|c|c|c|}
\hline \multirow{2}{*}{ No } & \multirow{2}{*}{ Identified Activity } & \multicolumn{3}{|c|}{ Expert Judgement } \\
\hline & & Yes & No & Conclusion \\
\hline 1 & Position Survey & $100.00 \%$ & $0.00 \%$ & Yes \\
\hline 2 & Adjustment Material Installation & $100.00 \%$ & $0.00 \%$ & Yes \\
\hline 3 & $\begin{array}{l}\text { Precast Parapet Panel Shifting from Trailer to } \\
\text { Top of Deck Slab }\end{array}$ & $100.00 \%$ & $0.00 \%$ & Yes \\
\hline 4 & Precast Parapet Panel Distribution & $100.00 \%$ & $0.00 \%$ & Yes \\
\hline 5 & Precast Parapet Panel Installing & $100.00 \%$ & $0.00 \%$ & Yes \\
\hline 6 & Precast Parapet Panel Fixing & $100.00 \%$ & $0.00 \%$ & Yes \\
\hline 7 & Rebar Installation for Concrete Stich & $100.00 \%$ & $0.00 \%$ & Yes \\
\hline 8 & Formwork Installation for Concrete Sticth & $100.00 \%$ & $0.00 \%$ & Yes \\
\hline 9 & Sealing Work & $80.00 \%$ & $20.00 \%$ & Yes \\
\hline 10 & Concrete Casting & $100.00 \%$ & $0.00 \%$ & Yes \\
\hline 11 & Formwork Dismantling & $100.00 \%$ & $0.00 \%$ & Yes \\
\hline
\end{tabular}


Table 4. Respondent Characteristics

\begin{tabular}{|c|c|c|}
\hline A & Experience & Total Sample \\
\hline 1 & $10-15$ Years & 13 \\
\hline 2 & $16-20$ Years & 10 \\
\hline 3 & $20-25$ Years & 5 \\
\hline 4 & $>25$ Years & 2 \\
\hline \multicolumn{2}{|r|}{ Total Sample } & 30 \\
\hline $\mathrm{B}$ & Position & Total Sample \\
\hline 1 & Manager & 5 \\
\hline 2 & Assistant Manager & 4 \\
\hline 3 & Staff / Engineer & 21 \\
\hline \multicolumn{2}{|r|}{ Total Sample } & 30 \\
\hline $\mathbf{C}$ & Education & Total Sample \\
\hline 1 & Diploma Degree & 3 \\
\hline 2 & Bachelor Degree & 22 \\
\hline 3 & Master Degree & 5 \\
\hline \multicolumn{2}{|r|}{ Total Sample } & 30 \\
\hline D & Country of Origin & Total Sample \\
\hline 1 & Japan & 4 \\
\hline 2 & Indonesia & 21 \\
\hline \multirow[t]{2}{*}{3} & Philippines & 5 \\
\hline & Total Sample & 30 \\
\hline
\end{tabular}

Table 5. Respondent Survey Results

\begin{tabular}{|c|c|c|c|c|}
\hline \multirow{2}{*}{ No } & \multirow{2}{*}{ Identified Activity } & \multicolumn{3}{|c|}{ Survey Result } \\
\hline & & Yes & No & Conclusion \\
\hline 1 & Preparation & $100.00 \%$ & $0.00 \%$ & Yes \\
\hline 2 & Position Survey & $100.00 \%$ & $0.00 \%$ & Yes \\
\hline 3 & Adjustment Material Installation & $100.00 \%$ & $0.00 \%$ & Yes \\
\hline 4 & $\begin{array}{l}\text { Precast Parapet Panel Shifting from Trailer to } \\
\text { Top of Deck Slab }\end{array}$ & $86.67 \%$ & $13.33 \%$ & Yes \\
\hline 5 & Precast Parapet Panel Distribution & $93.33 \%$ & $6.67 \%$ & Yes \\
\hline 6 & Precast Parapet Panel Installing & $100.00 \%$ & $0.00 \%$ & Yes \\
\hline 7 & Precast Parapet Panel Fixing & $100.00 \%$ & $0.00 \%$ & Yes \\
\hline 8 & Rebar Installation for Concrete Stich & $100.00 \%$ & $0.00 \%$ & Yes \\
\hline 9 & Formwork Installation for Concrete Sticth & $100.00 \%$ & $0.00 \%$ & Yes \\
\hline 10 & Sealing Work & $83.33 \%$ & $16.67 \%$ & Yes \\
\hline 11 & Concrete Casting & $100.00 \%$ & $0.00 \%$ & Yes \\
\hline 12 & Formwork Dismantling & $100.00 \%$ & $0.00 \%$ & Yes \\
\hline 13 & Finishing Works & $100.00 \%$ & $0.00 \%$ & Yes \\
\hline
\end{tabular}

